B. E. Nosenok, 1st year student of the educational level "Master"

Faculty of Philosophy, Branch of Culturology

Taras Shevchenko National University of Kyiv

60 Volodymyrska Street, Kyiv, 01033, Ukraine

\title{
DECADENCE-LITERATURE: THE IMAGERY SPECIFICITY
}

This article is devoted to the imagery problem of the decadence-literature (as a general phenomenon that periodically repeats itself) and of the literature of the decadency (as an oeuvre of crisis developments in art of the late 19th and early 20th century). The decadence-literature is a manifestation of the irreducibility. It is proposed to analyze the imagery based on the context of the modernist interpretation of the image / icon. Before the image was considered together with its mimetic foundation - as an imitation of the external world. But here the image is freed from its mimetism, and it turns into a kind of "immediate ontology" (it is the Gaston Bachelard's term). The classical structure of the image (plot, storyline, composition) ceases to play a leading role, and gives way to a writing. The decadence-literature image lets visual elements into literature. Therefore, there is a displacement from the ontology of the image to the image as an ontology in the research of imagery. It is also important to use the methodology proposed by Georges Didi-Huberman and Paul Virilio: the combination of the hermeneutic approach in the philosophy of image with elements of psychoanalysis, and the method of dromology, which is the connection of special aspects of the physics, mathematics and philosophy. The methodology of the School of Sociology of Imagination is also appropriate. The image of the decadence-literature is marked by symbolism, imaginism (it is also known the same direction in literature-with the same name). There is also the "genres-werewolves" when a work is called, for example, poetry in prose. A personality of the writer-author plays a great role here: the decadence-literature is saturated with a psychology and a biography that is turned inside out. It is the expression of the world of unforgiven, restless personalities, which is explained by the principle of creation from an absence, emptiness, depressive and melancholic states (nostalgia, fatigue, sweet melancholy). It's interesting that decadent moods contribute to creation here. Distinctive features of the authors of decadence-literature: soreness, tenderness, hypersensitivity, a difficult life path and an unstable world. The imagery that is generated by creativity of these individuals is marked by a special attitude to time and space, it is also directed to the past in an attempt to find a lost paradise - that existed before the crash.

Key words: image, literature, decadence, irreducibility, visual, "spooky action at a distance", memory, oblivion.

УдК 379.82(477)

О. Ю. Павлова, д-р філос. наук, проф. Київський національний університет імені Тараса Шевченка вул. Володимирська, 60, м. Київ, 03022, Україна invinover19@gmail.com

\section{ДО ДЕФІНІЦІї ПОНЯТТЯ "КУЛЬТУРНА ІНДУСТРІЯ": ДЕСКРИПЦІЯ СИМПТОМІВ ТА АНАЛІЗ ТЕНДЕНЦІЙ}

Стаття присвячена аналізу такого феномена сучасності, як культурна індустрія, який містить дві зустрічні тенденції: індустріалізацію виробництва об'єктів культури й культурофікацію індустрії. Перша передбачає наявність таких симптомів сучасності, як модерністський варіант комодифікаціі об'єктів культури (творів мистецтва, університетської освіти тощо), а також їх масове тиражування. Крім того, зазначена тенденція містить наступні позиції: комодифікація споживання, втрата культурними об'єктами регулятивної і критичної функцій, а також проективність культурного виробництва. Зворотна тенденція культурофікації індустрії містить наступні аспекти: редукція комерційних цілей культурного виробництва, "економіка знаків"; зростання ролі культурної компетенції у процесі власне індустріального виробництва, зменшення вартості матеріальної складової продукції.

Ключові слова: культурна індустрія, індустріалізація культури, культурофікація індустрії, індустрія, виробництво, споживання, сигніфікація

Постановка проблеми. Культурну індустрію зазвичай визначають у перспективі індустріалізації культури (1). Проте не менш важливою є протилежна позиція культурофрікація індустрії ("culturification of industry", термін С. Леша) (2). Нетотожність обох тенденцій відзначав ще Т. Адорно, фрундатор концепту культурної індустрії, що був уперше сформульований у їх спільній з М. Хоркхаймером роботі "Діалектика Просвітництва", потім вони неодноразово поверталися до даної проблематики. Критичному характеру позиції представників Франкфуртської школи, що розглядали культурну індустрію як спосіб створення та маніпуляції масами (нова антропологічна модель), був протиставлений науково-освітній проект представників Бірмінгемської школи Cultural studies. У його межах була здійснена спроба реабілітації "масової культури" як продукту творчості народу та підстави демократизації культури. Зокрема, цей сенс був укладений у концепцію "довгої революції" Р. Вільямса [11]. Обидві школи підкреслювали особливу роль мистецтва та способу його тиражування для процесу функціонування культури індустріальним способом. Ця теза не $є$ випадковою, оскільки в європейській культурі власне художнє поле було авангардом формування секулярної культури, у найбільш наочній фрормі пройшло етап інституалізації, зокрема стало втіленням високої культури та, нарешті, найшвидше позбавляється претензії на автономію (ніж інші форми духовної культури, зокрема наука та мораль). Саме "дегуманізація мистецтва" стала не лише підставою рефлексії, а й лабораторією для "повстання мас". Тому ми в даному дослідженні куль- турної індустрії обмежимося аргументацією зсувів в естетичній ссрері. Хоча домінування в постсучасності настанов корпоративної етики або формування технопарків як інтегративного вектору розвитку науки та промисловості можна також визначати в термінах індустріалізації культури (як і багато інших тенденцій).

Аналіз досліджень і публікацій. Інтерес до економічної ефективності сфери культури виникає в таких економістів, як В. Баумоль, В. Боуен, М. Блауг, В. Гінзбург, А. Кламер, П. Сакко, А. Скот, Д. Тросбі, Р. Тьюз, Б. Фрей, Д. Хезмондалш. Їх дослідження були переважно зорієнтовані не на природу даного феномена, а на управлінські проблеми з метою отримання більшого прибутку. 3 іншого боку, виникає інтерес у сфері соціології культури щодо перспектив організаційного та економічного функціонування зазначеної сфрери. У цьому ракурсі варто відмітити роботи Т. Адорно, П. Бурдьє, Т. Веблена, Р. Вільямса, С. Леша. Для розуміння специфріки культурної індустрії та режиму її сигніфікації важливо звернутися до робіт таких теоретиків мистецтва, як В. Беньямін, П. Вірільйо, Г. Ґадамер, Б. Гройс, М. Гайдеггер, Я. Мукаржовський, П. Рікер, Ж.-П. Сартр.

Мета статті: сформулювати базові настанови зазначених тенденцій становлення культурної індустрії та визначити підстави їх диференціації, синтезу та способу сигніфрікації.

Виклад основного матеріалу дослідження. Загальнокультурною очевидністю сучасності $€$ така тенденція, як індустріалізація об'єктів культури (1), чиї симптоми ми розглянемо окремо й більш докладно. 


\section{1. Модерністський варіант комодифрікації ку-} льтурних об'єктів

Останню не слід плутати з просто товарним обігом об'єктів культури, зокрема творів мистецтва. Формування "ринку символічної продукції" $є$ умовою становлення автономії художнього поля, тобто звільнення продуктів високої культури від контролю ремісничих корпорацій. Це має своїм наслідком диференціацію закритого та відкритого художнього виробництва, його соціальних структур, а також становлення інституту художньої критики як посередника між ними. Як переконливо доводить французький дослідник П. Бурдьє, твір мистецтва функціонує у двох вимірах: як товар (гетерономія ринку, що самоорганізується) і як образ (автономія художнього поля, що здійснюється через дисфункціоналізацію речі й формування принципу "вираження" (Г. Ґадамер)). Обіг творів мистецтва як об'єктів культури, з одного боку, руйнує диктат ремісничої корпорації з її вимогами шедевра, але водночас "виставляє" (з усіма гайдеггерівськими негативно-оціночними конотаціями) твір мистецтва як товар на продаж. Для того щоб твір мистецтва міг здійснюватися як товар, він, по-перше, повинен мати змогу пересуватися з публічного простору в приватний (саме цим пояснюється успіх "малих голландців"), а по-друге, художник як найманий робітник утілює у твір мистецтва певну вартість (в єдності міновоїспоживчої вартості й цінності). І лише тоді художня цінність як єдність майстерності зображення прекрасної форми та оригінальності художнього змісту втіленого образу $є$ підставою претензії на автономію поля мистецтва. Тобто апріорність принципу певної критичної здібності передбачає дисфункціональність речі. Образ у режимі "естетичного реалізму" (С. Леш) являє собою репрезентацію одного типу сутностей іншим типом сутностей. Тим самим автономія означає культивування власної логіки художньої сфери та дуалізм реальностей.

Британський дослідник С. Леш підкреслює, що, на відміну від цього, символізм премодерних цивілізацій не передбачає окремих реальностей. Символи, як доводять представники Cultural studies, зокрема С. Холл [9], отримують означення іманентно, тоді як трансцендентний статус образу свідчить не лише про диференціацію культурного та соціального, але й диференціацію сфери секулярної культури. Так, образ культивує художню реальність тим, що розриває зв'язок із повсякденним, соціальним, а також з науковим та моральним. Він має претензію виражати тільки внутрішній світ митця. Обидві реальності створюють та зберігають свою власну цілісність та порядок речі.

На субстанціональний статус речі претендує і сам художній образ. Ж.-П. Сартр пояснює: "Колір, який став річчю, він (художник) переносить на полотно та здійснює єдину трансрормацію: перетворює в уявний об'єкт. Таким чином, він не розглядає кольори й звуки як мову. Те, що може бути застосовано до елементів художньої творчості, можна застосувати й до більш складних їх комбінацій: художник не збирається зобразити на полотні знаки, він хоче створити річ" [7]. Тому цей фрранцузький фрілософр правомірно описує функціонування слів у поезії як речей, а не знаків. Навпаки, в структурах літературного тексту слова функціонують як знаки. 3 цим погоджується відомий чеський естетик Я. Мукаржовський. Останній зазначає відмінність поетичної та літературної норми та помилковість розгляду поетичної мови як різновиду літературної [6, с. 326]. Референціальна семантика образу здійснюється через заперечення гетерономності (соціального, релігійного, наукового та мораль- ного). Художній твір здійснюється як річ. Художній образ претендує вказувати лише на самого себе, але досягається це тим, що апріорний принцип доцільності художньої сфери як форми високої культури здійснюється лише через заперечення соціального. Виробництво в художній сфері отримує статус творення як способу самовираження творця як генія. Споживання нівелюється до споглядання та судження смаку, якому можна навчитися. Отже, художнє споглядання є другорядним до принципу вираження та оригінальності творення образу. Міра секуляризації культури та автономії художньої сфери корелює зі зсувом у способі сигніфрікації від символізму до реалізму (терміни С. Леша).

Останній ставить проблему майстерності митця при створенні певного художнього змісту. Художня творчість як майстерність значно трансформується в умовах технізації виробництва зображень. Науковотехнічний розвиток суттєво впливає на конфігурацію художнього поля:

1) Розвиток залізних доріг робить легким пересування та близькими раніше недосяжні простори. Художня лабораторія із закритого простору майстерні переноситься на відкрите повітря. Пленер значно розширює кольорову палітру живопису, дозволяє розкрити нові можливості зображення природи.

2) Розвиток хімічної промисловості створює новий тип фрарб, а також спосіб їх упаковки. Широко відоме висловлювання П.-О. Ренуара про те, що без тюбика не було б ані К. Моне, ані П. Сезанна, ані імпресіонізму взагалі. Так само як технологія олійних фарб уможливила художню своєрідність станкового живопису, художні фарби на хімічній основі в тюбиках забезпечили прорив імпресіонізму.

3) Особливу роль у промисловому виготовленні речей та їх продажу відіграє синтез естетичного та функціонального. Проте проблема дизайну, яка $€$ симптомом руйнування автономії художнього та формою трансформації "демонстративного споживання" (Т. Веблен), на нашу думку, $є$ дуже складною, потребує окремого вивчення й зазначається нами лише як окрема дослідницька перспектива.

4) Виникнення фотографії робить безглуздим майстерне відтворення всіх деталей та дрібниць, дозволяє зафріксувати тіло в таких неймовірних позах, яких ніколи б не змогла забезпечити вимушена статичність натурщиків.

5) Наступна жертва технізації зображення - це художня композиція. Французький дослідник П. Вірільйо говорить про те, що фотографічний ракурс як "фіксація точки зору" принципово відрізняться від легітимації "картини світу". Технічні можливості фотографії зберігають певним чином ефект рамки, проте здійснюють девальвацію позиції індивіда, результатом якої стає руйнація композиції як засадничої основи живопису, а також "розпад погляду" [2]. Висловлювання фрранцузького мислителя $є$ дуже близьким до позиції В. Беньяміна, який говорить, що "фотографрія готує тотальне відчуження між людиною і її оточенням, відкриваючи вільне поле, в якому будь-яка близькість поступається місцем точному відображенню деталей" [1].

6) Наступний крок у розвитку синтетичних мистецтв, що в першу чергу передбачає синтез мистецтв, техніки, кіно, приводить до реставрації іншого феномена світу мистецтва - колективного глядача. Останній багаторакурсністю масового споживача створює "орнамент маси" (3. Кракауер), що принципово не вписується в "картину світу". В. Беньямін у "Скороченій історії фотографії" пояснює це так: "Кіно пропонує матерію (предмет) одночасного колективного сприй- 
няття, як це було з давніх часів з архітектурою" [1]. Тим самим кіномистецтво, як і архітектура, не передбачає індивідуального глядача та, відповідно, легітимації погляду на світ. Хоча екранне мистецтво ще зберігає "ефект рамки" (Г. Зіммель). Проте самі функції рамки також трансформуються та потребують додаткової опори для власного здійснення.

Класичні твори мистецтва не потребували оформлення виставковим простором музеїв та галерей для підтвердження статусу своєї художньої цінності. Ïх спосіб здійснення, тобто художній статус, був загальнокультурною очевидністю. Достатньо було "ефекту рамки" для здійснення всезагального змісту естетичного судження та виокремлення художнього твору з простору приватності. Для того щоб стати художником, тобто виробником художньої цінності, що втілена у твір мистецтва, майстер мав здійснити емансипацію від корпорації ремісників, як яскраво зумів довести це П. Бурдьє. Тим самим (ринковий) обіг художніх творів як об'єктів культури $є$ умовою становлення в епоху раннього Модерну самого "прекрасного мистецтва". Поза формуванням ринку символічної продукції такого не могло статися, оскільки всезагальність стихії ринку служила підставою єдності для протиставлення автономії художньої сфери. Переміщення картини як продукту виробництва закритого художнього поля в приватний простір вимагало підтримки "ефектом рамки" навіть за наявності антиномії смаку. Переміщуючись з церкви в дім буржуа, культурний об'єкт 3 предмета культу перетворюється на художній твір. Лише рамка картини втримує його від просідання в повсякденність. Для отримання статусу знаку вже просто ефекту рамки не вистачає. Такий культурний об'єкт додатково потребує простору музею або галереї для підтримання власного статусу, тобто вимагає інституціональної підтримки.

Технологія фотографії і технізація процесу формування образу (що постає як можливість самовиробництва культурного змісту) спричинює зсув статусу автора. Відтепер образ як спосіб легітимації ракурсу погляду на світ не потребує удосконалення технічних можливостей ремісника. Копіювання дійсності делегується технічним винаходом та редукується до моменту фіксації минулого, як зазначає В. Беньямін. Тепер будь-яка людина 3 фотоапаратом здатна створити певне зображення. Вона може не лише зафріксувати певні копії своїх ракурсів світу, але й скласти власний образ життя з цих уривків за допомогою монтажу. Отже, творчість полягає не просто/ лише у створенні зображень, а в їх певному функціонуванні. Тим самим технологізація зображень делегує певний вимір акту творення масовому споживачу й закладає основи де-диференціації виробництва та споживання.

Але чи $€$ таке зображення образом? Деякі дослідники намагаються обґрунтувати презумпцію художньої фотографрії. Творчість модерністських митців підштовхує до негативної відповіді на це запитання. Привілей автора відтепер зміщується від майстерності уречевлення оригінального образу як носія альтернативної, автономної реальності до надання художнього статусу наявній речі, підкреслює сучасний дослідник Б. Гройс.

В епоху технізації виробництва зображень виникає необхідність нових стратегій виробництва образу. Для того щоб бути не просто найманим робітником художнього виробництва, стає необхідним новий крок на шляху до емансипації творчості, що девальвується 3 боку технічних засобів. Митець не може просто втілювати свою творчу силу в речі, надаючи їм прекрасної форми. Відтепер пафос творчості зміщується від вироблення до комерції зображення. Художник вчиняє не як робітник, а як комівояжер, тобто пересуває наявні культурні об'єкти з однієї сфери в іншу: з банальності приватної сфрери в надзвичайність публічності. Класичним $€$ приклад з "Фонтаном" М. Дюшана, але багато хто, починаючи з футуристів і аж до сьогодні, намагається дотримуватися цієї логіки комерціалізації образу. Митець діє вже не як виробник речі, а як комерсант. Він переводить річ з того місця, де вона не мала загальної значимості (тільки функціональну, приватну), у сферу, де вона не зводиться до свого утилітарного, матеріального втілення. Але завдяки співвіднесенню 3 іншим контекстом культурний зміст стає полісемантичним. Тим самим митець стає не виробником художнього твору як носія символічної вартості, а є комерсантом, підприємцем, що пересуває культурний об'єкт в інший культурний простір і тим самим надає йому символічну вартість. Спекуляції навколо символічного змісту культурного об'єкта є достатніми для багатьох дослідників культурної індустрії. Символічність культурної продукції виявляється "священною коровою", рефлексія над природою якої виявляється непотрібною. Символічність додаткової вартості виникає не як результат опредметнення людської діяльності, а як зсув об'єкта в інший культурний простір. Необхідно мати певний культурний капітал митця, щоб легітимно здійснити дану художню комерцію. Така собі форма художньої спекуляції, але вона потребує розуміння та обґрунтування. Без претензії на художність аналогічну комерцію намагається здійснити реклама.

Подібне відбувалося у процесі секуляризації культури. Предмети релігійного культу при переміщенні у профранну сферу залишалися без своєї сакральної функції, тобто дис-функціоналізувалися. Вони починали здійснюватися в секулярній культурі як твори мистецтва. Спочатку це відбулося з раритетами Античності. Вони вже в християнській культурі не були священними, але зберігали свій демонічний потенціал язичницької спокуси. Вченість ренесансних гуманістів позбавила їх поганської небезпеки, але разом з тим забрала й останні шари священного.

Між тим і християнські за змістом артефакти при пересуванні в приватну сферу відтепер могли претендувати лише на ауротичність мистецтва. Тим самим, доводить В. Беньямін, художня сфера постала як світська форма священного. Проте автономія художньої сфери забезпечувала самореферентність і водночас необхідність уречевленості образу. Так, пам'ятки архітектури були надто коштовними для того, щоб бути до кінця предметом "прекрасного мистецтва", а тому залишалися певною мірою в логіці утилітаризму, потлача та "демонстративного споживання", тобто інших типів культурних практик, ніж власне автономне художнє поле.

3 іншого боку, контекстуальність і дискретність культурного об'єкта як знаку водночас передбачають здійснення художньої цінності не в процесі уречевлення, тобто виробництва художнього твору, а як розкриття його семантичного значення, проявлення інтенції художнього в наявному. Проте семантика художнього в модернізмі припиняє бути референційною.

Митець у даному контексті виступає власником зазначеної "додаткової символічної вартості" (Б. Гройс) та висуває мету гонитви за нею головним сенсом своєї діяльності. Тим самим з робітника митець перетворюється на представника дрібної (або не дуже) комерції. Саме в цьому полягає претензія С. Далі на художню цінність його розпису як витвору мистецтва. Тим самим уже на рівні авангарду відбувається комодифікація мистецтва як крок на шляху до індустріалізації куль- 
тури. Виробництво художньої цінності відтепер проявляється не у виробництві речі, а у формуванні контексту як середовища. Інтенціональність стає альфою та омегою культурного виробництва.

Проте, як правильно помітив Б. Гройс, теоретик мистецтва залишається таким самим виробником ідеї, критичного змісту, що потребує безпосереднього матеріального втілення. Тим самим художня практика вже стала індустрією культури, у той час як рефлексія (поза іï де-диференціацією в художній сфері та інших видах культурних практик) залишається на організаційному рівні капіталізму XIX століття як : 1) виробництво письма (тобто слів як речей); 2) викладацька діяльність, тобто в логіці фрормування громадянина національної держави. Лише в інтернет-сфері, перетворюючись на видовище, освітня діяльність починає функціонувати за логікою підприємництва. Комерціалізація освіти, з одного боку, зменшує перспективи університету як сфери виробництва нації (у першу чергу за рахунок академічної мобільності), а з іншого боку, підвищення рівня зацікавленості, розважальності підриває дисциплінарність практики "героїв розуму" та пропонує інший вердикт у "суперечках про факультети" (І. Кант).

Отже, модерністський спосіб комодифікації об'єктів культури полягає не в тому, що вони стають товарами, як пропонують розуміти більшість сучасних дослідників культурної індустрії. Цей етап формування ринку символічної продукції був необхідним кроком ще в епоху матеріального втілення творів мистецтва, тобто на етапі раннього Модерну. Навіть модерністська комодифрікація передбачає не просто інтенсивність товарообігу об'єктів культури (тобто лише в кількісному сенсі), а комерціалізацію образу (і навіть спекуляцію) як спосіб виробництва об'єктів культури. Це означає реорганізацію художнього виробництва замкнутого типу та домінування режиму сигніфікації знаку. Після перемоги жесту дебаналізації як привілею статусу митця логічним чином виникає необхідність розуміння специфіки наступного кроку індустріалізації культури - масового тиражування образів.

\section{2. Масове тиражування культурних об'єктів}

Ця "альфа і омега" тез про індустріалізацію культури, починаючи з базової роботи В. Беньяміна, $€$ не просто технічною можливістю необмеженого копіювання, але також іншим виміром принципової зміни настанов художнього виробництва та статусу митця. Художник раннього Модерну відрізнявся від ремісника тим, що його продукція мала статус високої культури. В іншому, зокрема в самій технології виробництва, він залишався робітником, що об'єктивує свої зусилля та здібності в певному матеріальному продукті. Від ремісника його відрізняла лише якість підготовки. Дуже влучним у цьому контексті $€$ оповідання, в якому багатій висловлює обурення з приводу ціни за картину, яку митець намалював за три дні. На що художник йому відповідає, що він учився двадцять років для того, щоб зробити твір за цей короткий термін.

Модерністський тип комодифрікації передбачає зміну способу сигніфікації, зсув здійснення культурних об'єктів від образу до знаку у двох вимірах. Привілей авторської позиції в пізньому Модерні постає як виокремлення двох перспектив: перша - який жест повсякденності буде вирваний з контексту життєвого світу та виставлений на всезагальний розгляд (те, що було розглянуто в 1.1), а 3 іншого боку, який саме зміст буде тиражуватися в повсякденності (сюрреалізм, реклама).

Другий жест модерністської комерціалізації видається протилежним першому: дещо не буде вирвано зі сфери приватності, а, навпаки, оригінальний художній образ актом тиражування може потрапити зі свого унікального "імагінативного простору" в будь-яку ситуацію, у будь-який контекст. Це означає розширення його аудиторії, проте приховує небезпеку баналізації. Проте обидві стратегії модернізму: дебаналізація та баналізація образу, не дивлячись на зовнішню можливість протиставлення, побудовані на єдиному способі сигніфікації - зміні контексту. Дана процедура підриває претензію на самореферентність образу й встановлює домінанту контекстуальності знаку.

\section{3. Реабілітація споживчої вартості}

Комодифікація в культурі раннього Модерну була результатом домінанти мінової вартості в продуктах виробництва. Проте економіка культури не обмежується функціонуванням лише у режимі виробництва, але й містить обов'язковий момент споживання - не лише як зовнішній та похідний по відношенню до мінової вартості. С. Леш формулює наступний склад елементів "економіки культури": 1) особливі взаємозв'язки у створенні об'єктів культури; 2) особливі умови сприйняття об'єктів культури; 3) особливі інституційні рамки, що виступають посередниками між створенням об'єктів культури та сприйняттям; 4) особливий спосіб, за допомогою якого відбувається обіг об'єктів культури [4, с. 1112]. Можна погодитися з тезою цього британського мислителя про необхідність реабілітації споживання для розуміння специфріки де-диференціації соціального та культурного. Проте в даній цитаті споживання $є$ редукованим до сприйняття, що тяжіє до споглядання, тобто до духовної форми споживання.

Ми вже відмітили дві тенденції зміни настанов споживання: 1) його колективізація, тобто, якщо можна так сказати, виникнення "орнаменту маси" як колективної форми споживання; 2) технізація зображення призводить до масовізації виробництва копій (реальних речей (1.1) та художніх репродукцій (1.2)). Отже, можна говорити про перетворення споживання на вид виробництва. Проте зміна статусу споживання в модерністському варіанті комодифікації та індустріалізації культури потребує пояснень.

Безумовно, рання модерна фрорма домінування мінової вартості над споживчою, яка зокрема проявляється в тому, що виробництво зорієнтоване на власні потужності, а не можливості споживання, проявляється у відсутності загальноприйнятих термінів. Так, британський дослідник Р. Вільямс говорить про проблеми нездатності прямого стягування плати за "кожне використання" в процесі комодифрікації медіа. Уточнення споживання як використання медіа-продуктів відповідає процесу відновлення значимості останнього. Саме реставрація ролі споживання постає у зв'язку з процесом втрати важливості уречевлення мінової вартості та регулятивності ціннісної настанови.

Економіка послуг має своє продовження і в дії посередника як соціальної структури (що, наприклад, відбувалось при інституалізації художньої критики), і при її технізації. Тобто коли функція медіума делегується власне предмету. Проблема комодифікації послуг ускладнюється при розмиванні використання окремої речі в мережу або серію предметів, що яскраво описував Ж. Бодрійяр у роботі "Суспільство споживання". Відповідно, відбувається не просто комодифікація споживання, а де-диференціація мінової та споживчої вартості. Це означає, що споживання не є просто матеріальним використанням як знищенням (відомий гегелівський приклад із чоботами), але не $є$ і духовним споживанням як спогляданням. Відтепер рівновага мінової вартості та цінності полягає в реабілітації споживчої вартості. Це є умовою нової реінкарнації "демонстративного спожи- 
вання" як виробництва самого тіла суспільства поза антитезою матеріального та духовного. Це також передбачає проблему комодифікації процесу споживання як моменту індустріалізації культури. Сама фрорма "символічного обміну" є симптомом домінанти семантичного типу зв'язку.

1.4. Втрата культурними об'єктами регулятивної та критичної функцій

Вона $€$ похідною від процесу де-диференціації культурного та індустріального. Висока культура й була критичною позицією по відношенню до такого стану речей, який являла собою індустрія. Так, доцільність як апріорний принцип рефлексивної здібності судження передбачала, у першу чергу, заперечення корисності. Комодифікація образу є показником того, що мистецтво втрачає свою претензію на автономність та трансцендентальний статус свого базового принципу. Останнє виражається у втраті культурними об'єктами регулятивної та критичної функцій. Втрата референціальної семантики художнім містить певну "заангажованість" (Ж.-П. Сартр, П. Бурдьє), проте втрачає претензію на неупередженість, регулятивність, критичність, якими характеризувалися судження смаку.

1.5. Проективність культурного виробництва

Призводить до обумовленості художнього та в цілому культурного виробництва розміром фрінансування. Б. Гройс описує, що вибір технічного втілення, тобто матеріального носія, в логіці індустріалізації культури зумовлений розміром кредитування самого процесу художнього виробництва. У залежності від суми гранту обирається вид художнього втілення. Найбільш коштовним виступає відеопроект, більш дешевим - фотографрія. Найменшого рівня кредитування потребує малюнок, шуткує Б. Гройс. Тобто від свободи підприємництва художній жест модернізму рушив у царину проективності. Це відповідає тенденції повернення до художнього замовлення, що передбачає згортання вільної самоорганізації ринку символічної продукції.

Але слід зазначити, що це повернення до ринку замовлення $€$ більш характерним для художнього поля. Виробництво "естетики існування" поза масштабами можливостей самого виробництва здійснюється в Інтернеті. Більш точно, масштаби можливостей творчості розкриваються у віртуальному просторі самовиробництва, що приватизується в логіці індивідуалізації (3. Бауман, С. Леш). В інтернет-мережі, не дивлячись на те, що вона $€$ "крематорієм дематеріалізації" [3], самовиробництво стає настільки щільним, що майже всі (усі користувачі мережі) отримують статус творців власного профілю. Щільність такого самопродукування підкреслює те, що кількість публіки також тяжіє до нуля. Самоспоглядання порушується рідкими лайками близького кола переважно невіртуальних знайомих. Навіть професійні митці не мають більше успіху, ніж аматори та неофіти. Саме тому віртуальне мистецтво як художня практика залишилося нездійсненою мрією часів початку становлення інтернет-середовища, вважає арт- та медіа-критик Б. Гройс. Водночас навіть те, що має успіх у віртуальному просторі/мережі, відповідає не настановам художнього поля, а швидше естетичним практикам "демонстративного споживання" (Т. Веблен).

У цьому сенсі важливим $\epsilon$ те, що парадоксальна незацікавленість рефлективного судження, класично сформульована І. Кантом, що слугує підставою апріорного принципу доцільності сфери мистецтва, є принципово протилежною заангажованості демонстративного споживання. Останнє має своєю метою естетичними засобами вибудовувати соціокультурну ієрархію через позиціонування статусу привабливості свого носія. А тому вихідна зацікавленість демонстративного споживання не вписується в антиномію чистого судження смаку. Вона є принципово "варварською" у визначенні І. Канта, оскільки саме зворушливе та збудливе $€$ необхідним для отримання задоволення, а також покликана підтримувати приватний інтерес. Так, відомість, завжди жадана, але миттєва, стає метою позиціювання в інтернет-просторі. Процес отримання віртуального статусу відомості, що є провідною формою мотивації індивідуалізованого суспільства, яскраво описує 3. Бауман. Прагнення відомості симетричне до бажання слави в героїчному епосі Премодерну. Така слава виступає базовою формою культурного капіталу, що має більшу символічну вартість, ніж безпосереднє майнове багатство. Так, король Марк у кельтському епосі про Тристана та Ізольду звинувачує свого племінника в першу чергу не в тому, що він звабив його молоду дружину, а в тому, що забрав його славу воїна.

У практиках демонстративного споживання як отримання символічної вартості відомості важливою $є$ форма релятивізації суб'єкт-об'єктної опозиції, оскільки демонстративне споживання $є$ специфічним видом синтезу людини та речі. Специфіку його премодерної форми дуже добре пояснює медієвіст А. Гуревич у роботі про сагу через зрощення епічного героя зі своєю зброєю, конем та іншими атрибутами. У Постмодерні віртуальне позиціювання людини стає можливим завдяки посередництву нових медіа, що являють собою синтез технічного, соціального та культурного. Тим самим у процесі індустріалізації культури поступово проступає зворотна тенденція де-диференціації, що має інші виміри.

2. Тепер зупинимося на протилежній тенденції культурофрікаціі індустрії, що містить у собі наступні моменти.

2.1. Втрата комерційних цілей культурного виробництва

Принаймні процес виробництва так ускладнюється й опосередковується, що втрачає безпосередність зв'язку 3 прибутком. Ще Т. Адорно висував дану тезу, але більш підкреслював значення ідеології, що випадає 3 логіки прямого прибутку через абсолютизацію регулятивності. Проте декомерціалізація в процесі культурної індустрії містить інші конотації. Наприклад, кіновиробництво має достатньо пряму комерційну віддачу. Телебачення більше пов'язане з доходами від реклами. Інтернет-продукція має настільки складну та опосередковану форму відплати, що далеко виходить за межі реклами.

\section{2. Економіка знаків}

Визначення культурної індустрії як "економіки знаку" або "символічного обміну" $є$ базовою настановою сучасних дослідників (Ж. Бодрійяр, П. Гай, С. Леш, М. Прайк, Д. Тросбі). Дану тезу ми б хотіли розглянути лише в одному ракурсі. Перспектива проблематизації речі відповідає їі характеру дискретності як матеріального носія. У чому полягає відмінність дискретності речі та дискретності знаку в процесі обміну? Знак - це проблема межі сенсу з вказівкою на інший сенс. Проблема обмеженості, визначеності (встановлення межі, за Б. Спінозою) речі в її матеріальних параметрах. Річ у логіці абсолютизації суб'єкт-об'єктної опозиції передбачає субстанціональний статус. Зсув у режим сигніфікації модернізму передбачає проблематизацію референціальної семантики та підкреслення самореферентності знака. 3 цього пункту, власне, й починав Ф. де Соссюр.

Знак завжди також вказує на інше (інший знак), тобто завжди є контекстуальним. Але він: 1) вказує не на себе, а на інше, передбачає культивування відмін- 
ності; 2) проте саме цей певний спосіб вказування, а не інший передбачає перспективу специфікації знаку. Знак являє собою апроксимацію проблеми змісту та актуалізацію проблеми форми (як формалізму) саме тому, що сама вказівка може бути репрезентована різними знаками. I навіть від питань прагматики - між якими суб'єктами ці знаки циркулюють та як їх способи вказування функціонують - також можна певним чином відсторонитися. Тим самим "план семантики" (П. Рікер) домінує над прагматикою. Колообіг знаків опосередковує саме відношення між знаком та суб'єктом комунікації. Таким чином економіка товарів як матеріальних носіїв у режимі сигніфікації модернізму та відповідної моделі економіки культури перетворюється в економіку знаків. Останні характеризуються "підвищенням швидкості обігу та зменшенням строку служби суб'єктів та об'єктів" [5, c. 51]. Саме в цьому контексті Г. Ґадамер підкреслював значимість "актуальності прекрасного", оскільки в художньому творі не здійснюється девальвація речі.

\section{3. Зростання ролі культурної компетенції}

Навіть у процесі власне індустріального виробництва вже ссрормувалися стандарти початкової грамотності як первісної форми культурної компетенції. При зростанні знакового характеру виробництва дана характеристика посилюється. Ось як це описує С. Леш: "Зростаючий простір дозволяє подібній критичній рефлексивності розвиватися почасти завдяки більш активному поширенню культурних компетенцій [cultural competencies], а частково - у силу тенденції руйнування довіри до "експертних систем" нового порядку. У першу чергу ця зростаюча рефлексивність $€$ невід'ємною частиною радикального посилення індивідуалізації в епоху пізнього Модерну. Іншими словами, йде безперервний процес детрадиціоналізації, у ході якого соціальні агенти все більше "звільняються" від гетерономного контролю або спостереження з боку соціальних структур і замість цього залучаються до процесів самоспостереження або саморефлексії. Ця прискорена індивідуалізація є процесом, у ході якого дія вивільняється зі структури. У цьому процесі самі структурні зміни, які супроводжують модернізацію, підштовхують суб'єктів дії до того, щоб захопити владу, яка раніше належала соціальним структурам. Як наслідок ми бачимо, як структурні зміни в господарстві спонукають індивідів, наприклад, до звільнення від структурної жорсткості фрордистського процесу праці. Іншими словами, те, що робоча сила все більше тяжіє до самоспостереження [self-monitoring] й рефлексує з приводу правил і ресурсів створення робочого місця, стає все більш важливою передумовою структурних господарських змін і умовою накопичення капіталу. Тому ми досить уважно розглянемо, як розвивається процес рефлексивного накопичення [reflexive accumulation] в господарському житті" [5, с. 51]. Роль культурної компетенції кожного споживача культурної продукції означає, що він стає виробником власного життєвого середовища. Тобто виробництво образу як комерціалізація зображення також втрачає свій елітарний статус та претензію на здійснення художнього поля як закритого типу соціального виробництва. У мережевому суспільстві творчістю $є$ не комерціалізація образу, що працює в режимі знаку. Відбувається повернення до режиму означення символу, символу потоку.

2.4. Зменшення вартості матеріальної складової продукції

Це також означає підвищення вартості ідейної вишуканості (інноваційної, організаційної, дизайнерської) продукції. Це дозволяє ще більш спекулювати вартістю в цілому. Втрата речового втілення продукції культуріндустрії сприяє відриву товарного капіталу від виробничого, а фінансового від товарного.
Іншим виміром даної характеристики $€$ зростання естетизації культурних об'єктів. "У виробництві естетизація проявляється в тому, що вартість товару значною мірою визначається його дизайном, а характер трудового процесу вже не настільки важливий для виробництва доданої вартості. Це стосується навіть промислового виробництва - нині більш “дизайноємного” й пов'язаного 3 інтенсивною науковою дослідницькою діяльністю. Причому остання часто несе важливе естетичне навантаження - наприклад, стосовно таких товарів, як одяг, взуття, меблі, автомобілі, електроніка тощо. Споживчі товари тривалого користування постають свого роду вбудованим "мікросередовищем" будівель, приміщень, офісів, автомобілів тощо" [5, с. 52].

Художня цінність, що $є$ втіленою в річ, у грі контекстів функціонує як знак. Тим самим сенс здійснюється не систематично, а структурно. Окремі сенси в контекстуальному зв'язку є дискретними. Вони ґрунтуються швидше не на закономірності, а на випадковості авторитету відомості. Тим самим ідеологія як претензія свідомості на самодостатність, незаангажованість перетворюється на культурну гегемонію, тобто владу здійснювати зв'язок контекстів.

Реабілітація речі від ії лише товарного статусу $\epsilon$ базовою характеристикою постмодерністських розробок - від "парламенту речей" (Б. Латур) до "культурної біографрії речі" (І. Копитофрф). Дані позиції вказують як на підрив надзвичайного статусу суб'єкта, його самодостатності, так і на надання певних акторних функцій самим речам.

Наочна тенденція "естетизації повсякденності" вже була розглянута в пункті 1.1. "Фонтан" М. Дюшана поза виставковим контекстом перетворюється на банальність. Саме ця здатність до тиражування як включення в повсякденність або, навпаки, виставлення у позаповсякденність галерейного простору і $\epsilon$ головною креативною потужністю митця. Тим самим постать митця та експерта/критика розмивається. Здатність втілити в матеріальній формі особливий сенс перетворюється на можливість його розмноження як втілення в різні контексти або, навпаки, виштовхування того, що вже втілене, в матеріальний простір публічності. Тим самим ідеологія як демонізація суспільної свідомості, творення як втілення в певному шматку матерії особливого статусу перетворюються в умовах культурної гегемонії у творення самого статусу.

Проте естетизація повсякденності проявляється не лише в прикрашенні речі або певного середовища як "системи речей". Мистецтво не обмежується виробництвом речей, а претендує на виробництво естетичної події. Це було зазначено вже в тезах "мистецтва майбутнього" Р. Вагнера. Проте найбільш повно "естетика існування" як самовиробництва, як зазначалося вище, здійснюється у віртуальному просторі. Тут потоки образів життя затоплюють та навіть знищують не лише глядацьку аудиторію, а й розмивають ірраціональний залишок суб'єкт-об'єктної опозиції, на якому трималось "жорстке ядро Модерну". Сама парадоксальність культурних індустрій заснована на модерному протиставленні людини та речі. Проте етимологічний аналіз терміну "індустрія" виявляє, що так було не завжди.

Р. Вільямс визначає поняття індустрії як одне 3 ключових для культурних досліджень. Він присвячує йому окрему статтю у своїй авторській енциклопедії та звертається до етимологічного аналізу даного терміну в англійській мові. Цей авторитетний представник Cultural Studies говорить, що industrie можна зустріти 3 XV століття. Уже в XVI столітті у роботі відомого англійського дипломата та мислителя Т. Еліота "Наставник" 
(Thomas Elyot "The Boke Named the Governour") зазначається, що дане слово не так давно для тих часів увійшло в обіг англійської мови. Воно визначається як здатність людини до сприйняття нових винаходів і порад. Така спритність та працьовитість певною мірою протиставляється лінощам і тупості, що свідчить про певний ментальний характер описуваного френомена.

Латинське коріння endostruos англійського терміну industria, industrius означає "той, що будує в глибині, усередині". У християнській традиції воно пов'язане 3 концептом "божого промислу" з профетичним відтінком провіденціалізму. Секуляризація змісту терміну виявляє актуалізацію практичних умінь людини.

Такий наголос на спритності та вмілості раннього модерного сенсу англійського терміну industrie $€$ близьким до синкретизму слов'янського "промисел", в якому дієслово "промишляти" пов'язане з конотаціями полювання/риболовства та навіть грабування. Тобто це були швидше різновиди збирання та навіть привласнення, ніж власне виробництво. Лише поступово дрібне та кустарне ремісництва, що доповнювали в аграрному суспільстві першу історичну форму розширеного виробництва, отримають назву промислу. Досі промисловість, що зорієнтована на видобування природних ресурсів, зберігає свій премодерний зв'язок з привласненням, труднощами ручної праці та налаштованістю на важкий результат "праці та днів".

Ці конотації доброчесної працьовитості довго зберігаються в англійській мові: "Industrious, що означає або майстерний (вмілий), або посидючий, був загальнопоширеним прикметником у XVI столітті. 3 XVI століття 3'являються виведені (industrial) фрукти, у сенсі розрізнення культивованих (industrial) і природних рослин. Термін Industrial тоді застосовувався рідко або зовсім відсутній до XVIII століття, коли почався розвиток, який зробив його загальним 3 XIX століття. Можливо, було нове запозичення 3 французької мови" [10, р. 165]. Англійське industrial нове втілення римської cultural.

Лише поступово модерний сенс індустрії проступає в цьому слові. Хоча воно ще довго використовувалося як антонім лінощів і тупості, як синонім працьовитості, проте формується й більш вузький зміст - як методу роботи або пристрою. Помітні пуританські конотації поміркованості та наполегливості, у протилежність отіуму (священному нічого неробленню Премодерну). А також відтінок праці з пристроєм, річчю, інструментом. Те, що в подальшому буде розгортатися, тяжіти до індустріального, машинного виробництва. "Саме 3 XVIII ст. виникає смисл industry як інституту або сукупності інститутів, що почали виникати. У цьому було значення "Коледжу індустрії для всякої корисної торгівлі й землеробства" в 1696 році і подальших “шкіл" індустрії, пов'язаних з недільною школою. Але найбільш широкого використання набув у XVIII ст. "будинок промисловості”, робітний дім, де ідеї примусового застосування й корисної/успішної роботи прийшли разом. Тоді, в Адама Сміта, сформульоване модерне узагальнююче використання поняття: “...кошти, призначені для підтримки промисловості/індустрії” (“Багатство народів", 1776). 31840 р. та пізніше це використання терміну стало загальним: Б. Дізраелі - "наші національні галузі промисловості/індустрії” (1844); Т. Карлейль - “лідери промисловості" (1843). Сенс терміну "індустрія" як людської якості, а не установи/інституту продовжує використовуватися, але був підпорядкований попередньому сенсу після цього періоду" [10, р. 166].
Р. Вільямс ретельно розбирає використання конотації "індустрії" в роботах А. Безансон [8], а також В. Вордсворта, Ф. Енгельса, Р. Оуена. Він зупиняє увагу на введені терміну "індустріалізм" Т. Карлейлем у 1843 р. та "індустріальна революція" А. Тойнбі - у 1881-му . 3 цього часу загальнокультурною очевидністю стали "два різні (хоча перехресні) сенси: серії технічних винаходів (у якому ми можемо говорити про другу чи третю промислову революцію); а також у більш широкому, але й більш історично специфічному сенсі соціальних змін - інституту індустріалізму, або промислового капіталізму" [10, p. 167]. Р. Вільямс зазначає, що співвідношення між індустріалізмом та капіталізмом $€$ проблематичним та потребує уточнення. Відмінність між цими термінами зустрічається й у інших дослідників. Так, наприклад, відомий автор світсистемного аналізу І. Валлерстайн також відрізняє фази аграрного та індустріального капіталізму в історії європейської світ-системи.

Специфіка нового порядку виробництва, що починався 3 конкуренції економічних ефектів та технічних пристроїв, корелює з новим типом організації соціуму в цілому. Модерному ладу індустріальне суспільство відповідає своєю спрямованістю на модус часу. Адже економічна ефективність виробництва тут заснована на ідеї перманентного технічного оновлення, яке має випереджати "суспільно необхідний робочий час". Промисловий порядок організації соціуму разом із загальною настановою раціональної організації машинного виробництва формує власну соціальну структуру - промисловці та робочі. Сукупність різновидів промисловостей (легкої, важкої, вугільної) не суперечить організаційній єдності соціуму. Адже суспільний характер розподілу праці забезпечує "органічний тип" солідарності. Аграрна сфрера, яка довго залишалася немеханізованою (навіть при тотальній залученості в капіталістичні структури в більшій частині світу), стала індустріально організованою лише в першій третині XX століття, що остаточно систематизувало (тобто зробило єдиним на засадах певного принципу) матеріальне виробництво. Опозиція "промисловці та робочі" була екстрапольована на більш широкий соціальний контекст - роботодавці та (наймані) робітники. Дана опозиція замінила собою класичну тричастинну структуру Премодерну (oratores, bellatores, laboratores) та унаочнила модерне протиставлення соціального та культурного.

Де-диференціація даної опозиції здійснюється в американській за походженням термінології: індустрія святкова/розваг/дозвілля. Такі поняття формулюються вперше в такому розділі сучасної західної економічної науки, як "економіка культури" (Economics of Culture). Зазначені дослідження фріксують необхідність раціоналізації та уніфікації (останню Т. Адорно вважає навіть більш важливим атрибутом для культурної індустрії, ніж технізацію) сорери духовного виробництва. У цілому тенденції культурофікації індустрії та індустріалізації культури не суперечать аутентичному сенсу індустрії, якщо не забувати про її витоки та подвійне значення, на якому наголошує Р. Вільямс: "Є два основних сенси індустрії: (I) людська якість сталих прагнень або зусиль; (II) установа або сукупність інституцій для виробництва або торгівлі. Два сенси можна обережно розділити їх сучасними прикметниками працьовитий/умілий (industrious) i промисловий (industrial)" [10, р. 166]. Адже промисловість $€$ не лише використанням природного середовища, а й "неорганічним тілом людини".

Висновок. Таким чином, така загальнокультурна очевидність сучасності, як індустріалізація виробництва об'єктів культури (1), передбачає наявність таких сим- 
птомів сучасності: 1). модерністський варіант комодифрікації об'єктів культури (творів мистецтва, університетської освіти тощо), а також 2) їх масове тиражування. Крім того, зазначена тенденція містить у собі наступні позиції: 3) комодифрікація споживання; 4) втрата культурними об'єктами регулятивної та критичної фуннкцій; 5) проективність культурного виробництва.

Зворотна тенденція культурофрікації індустрії (2) містить наступні аспекти: 1) втрата комерційних цілей культурного виробництва; 2) "економіка знаків"; 3) зростання ролі культурної компетенції в процесі власне індустріального виробництва, 4) зменшення вартості матеріальної складової продукції.

Запропонована класифікація тенденцій та симптомів культурної індустрії не претендує на вичерпність та довершену систематичність. Вона покликана прояснити логіку становлення зазначеного френомена культури не лише як форми де-диференціації культурного (висока культура) та індустріального (історична форма суспільного), а й де-диференціації культурного та соціального взагалі.

Французький дослідник Г. Тард пропонував термін "суперсоціальне", сенс якого передбачає певне протиставлення власне соціальному (яке абсолютизує індустріальна організація суспільства). Але таке протиставлення $€$ не замиканням окремої соціальної складової як елітарної, а фрормуванням іншого типу суспільного в його синтетичній єдності з культурним. Зокрема, даний процес є синтезом людини та речі (як "парламент речей"), де-диференціацією матеріального та духовного, виробництва та споживання, отже, соціального та культурного. Культурна індустрія прояснює сенс культури як способу буття людини в ракурсі усталеності ії зусиль, способу їх інституалізації та сигніфрікації.

\section{СПИСОК ВИКОРИСТАНИХ ДЖЕРЕЛ}

1. Беньямин В. Краткая история фотографии [Електронний ресурс] / В. Беньямин; [пер. с нем. С. Ромашко] // В. Беньямин. Произведение искусства в эпоху его технической вопроизводимости. Избранные эссе. - Москва: Медиум, 1996. - С. 66-91. - Режим достуny:http://www.academyphotos.ru/library/benjaminkratrayaistoriya.pdf

2. Вирильо П. Машина зрения [Електронний ресурс] / П. Вирильо; [пер. с фр. А. Шестакова]. - СПБ: Наука, 2004. - 140 с. - Режим доступу: https://monoskop.org/images/1/19/Virilio_Paul_Mashina_Zreniya.pdf

Е. Ю. Павлова, д-р филос. наук, проф.

Киевский национальный университет имени Тараса Шевченко

ул. Владимирская, 60, г. Киев, 03022, Украина
3. Гройс Б. В сущности, современное искусство является теологией музея [Електронний ресурс] / Б. Гройс. - Режим доступу: http://www.colta.ru/articles/art/10713

4. Леш С. Соціологія постмодернізму / Леш С.; [пер. з анг. ю. Олійнік]. - Львів: Кальварія, 2003. - 344 с.

5. Лэш С., Урри Дж. Хозяйства знаков и пространства. Введение / С. Лэш, Дж. Урри [пер. М.С. Добряковой] // Экономическая социология. -2008 . - Т. 9. - № 4.- С. $49-56$.

6. Мукаржовський Я. Мова літературна і мова поетична / Я. Мукаржовський // Антологія світової літературно-критичної думки XX ст. [за ред. М.Зубрицької]. - Львів.: Літопис, 1996. - С. 324-343.

7. Сартр Ж.-П. Что такое литература? [Електронний ресурс] / Ж.-П. Сартр [пер. с фр. М. Драко]. - Минск: Попурри, 1999.- 448 с. Режим доступу: http://lib.ru/SARTR/s literatura.txt

8. Bezanson A. The Early Use of the Term Industrial Revolution [Електронний ресурс] / A. Bezanson // The Quarterly Journal of Economics. - 1922. - Vol. 36, №. 2. - P. 343-349. - Режим доступу: https://www.jstor.org/stable/pdf/1883486.pdf

9. Hall S., Resistance Through Rituals / S. Hall. - London: Hutchinson, 1976. $-178 \mathrm{p}$.

10. Williams R. Keywords: a Vocabulary of Culture and Society / R. Williams. - New York: Oxford University Press, 1983. - P. 165-168.

11. Williams R. The Long Revolution. / R. Williams. - Tonawanda: Broadview Press, 2001. - $399 \mathrm{p}$.

\section{REFERENCES}

1. Benjamin, W. (1996). A Short History of Photography (in Russian). Retrieved from http://www.academyphotos.ru/library/benjaminkratrayaistoriya.pdf

2. Virilio, P. (2004). The Vision Machine (in Russian). Retrieved from https://monoskop.org/images/1/19/Virilio_Paul_Mashina_Zreniya.pdf

3. Groys, B. (2016). V sushnosti, sovremennoe iskustvo yavlyayetsa teologiey museya [In Fact, Contemporary Art is Theology of the Museum]. Retrieved from http://www.colta.ru/articles/art/10713

4. Lash, S. (2003). Sociology of Postmodernism. Lviv, Kalvariya (in Ukrainian).

5. Lash, S., Urry J.(1994). Economika znaka i prostranstva. Vvedenie [Economies of Signs and Space. Introduction]. In Economicheckay sociologiya [Economic sociology], 4, 49-56.

6. Mukařovský, J. (1996). Mova literature ta mova poezis [Literary Language and Poetic Language]. In Anthology Svitovoy Literature, critichoy dumki XX stolitty [Anthology of the world literary critique of the $X X$ century]. Lviv, Litopis.

7. Sartre, J.-P. (1999). Chto takoe literatura? [What is Literature?]. Retrieved from http://lib.ru/SARTR/s literatura.txt

8. Bezanson, A. (1922) The Early Use of the Term Industrial Revolution. The Quarterly Journal of Economics. Vol. 36, 2. Retrieved from: https://www.jstor.org/stable/pdf/1883486.pdf

9. Hall, S. (1976). Resistance Through Rituals. London, Hutchinson.

10. Williams, R. (1983). Keywords: a Vocabulary of Culture and Society. New York, Oxford University Press.

11. Williams, R. (2001). The Long Revolution. Tonawanda, Broadview Press.

Надійшла до редколегії 24.05.17

\section{К ДЕФИНИЦИИ ПОНЯТИЯ "КУЛЬТУРНАЯ ИНДУСТРИЯ": ОПИСАНИЕ СИМПТОМОВ И АНАЛИЗ ТЕНДЕНЦИЙ}

Статья посвящена анализу такого широко изучаемого феномена современности, как культурная индустрия, которая включает две встречные тенденции: индустриализацию производства объектов культуры и культурофикацию индустрии. Первая предполагает наличие таких симптомов современности, как: модернистский вариант коммодификации объектов культуры (произведений искусства, университетского образования и т. п.), а также их массовое тиражирование. Кроме того, указанная тенденция включает в себя следующие позиции: коммодификация потребления, потеря культурными объектами регулятивной и критической функций, проективность культурного производства. Обратная тенденция культурофикации индустрии содержит следующие аспекты: редукция коммерческих целей индустриального производства, "экономика знаков"; возрастание роли культурной компетенции в процессе собственно индустриального производства, уменьшение стоимости материальной составляющей продукции.

Ключевые слова: культурная индустрия, индустриализация культуры, культурофикация индустрии, индустрия, производство, потребление, сигнификация.

O. Y. Pavlova, Doctor of Philosophical Science, Professor

Taras Shevchenko National University of Kyiv

60, Vladimirrvska Street, Kyiv, 03022, Ukraine

\section{TO THE DEFINITION OF THE CONCEPT "CULTURAL INDUSTRY": DESCRIPTION OF SYMPTOMS AND ANALYSIS OF TRENDS}

The article is devoted to the analysis of such extensively studied phenomenon of modernity as cultural industry, which includes two opposite tendencies: the industrialization of cultural objects production and the "culturification" of industry. The former presupposes the presence of such symptoms of modernity as: a modernist version of the commodification of cultural objects (works of art, university education, etc.) as well as their massive reproduction. In addition, this tendency includes the following positions: the commodification of consumption, the loss of cultural objects of their regulatory and critical functions, the projectivity of cultural production.

The reverse tendency - "culturification" of industry - contains the following aspects: the reduction of commercial goals of industrial production, the "economy of signs": an increase in the role of cultural competence in the process of actual industrial production, a reduction in the cost of the material component of the production.

The proposed classification of tendencies and symptoms of the cultural industry does not claim for exhaustiveness and completed systematicity. It is designed to clarify the logic of the formation of this phenomenon of culture, not only as a form of de-differentiation of cultural (in the sense of high culture) and industrial (as a historical form of social), but also as the de-differentiation of cultural and social ones in general. 
The industrial society, whose existence is the basis for the absolutization of the industry autonomy, is one of the historical forms of the social itself. In this type of society, cultural autonomy is realized as the closure of an elitist social structure. Withdrawal from an industrial society implies "Reassembling the social", a synthetic unity of social and cultural. In the logic of "liquidity of Modern" (opposite to solidity) and of the subject-object opposition, this process manifests itself in the process of human and things synthesis (as a "Making things public"), that is, in the de-differentiation of material and spiritual production and consumption, is therefore in social and cultural. The definition of the cultural industry clarifies the meaning of culture as a way of being a human in the perspective of the sustainability of his efforts, the kind of their institutionalization and signification.

Keywords: cultural industry, industrialization of culture, culturafication of industry, industry, production, consumption, signification.

УдК 130.2:101.1:17.023:179.9(450)

М. М. Рогожа, д-р фрілос. наук, профр. Київський національний університет імені Тараса Шевченка вул. Володимирська, 60, м. Київ, 01033, Україна mrogozha@ukr.net

\section{ФІЛОСОФ У ПРОСТОРІ І ЧАСІ КУЛЬТУРИ (ХРОНОТОП ЖИТТЕВЧЕННЯ). ЧАСТИНА І}

Стаття присвячена осмисленню філософського способу життя як інваріанта західної культури. У статті містяться відповіді на питання: який вплив на особу, яка мислить, мають час і місце її життя $і$ чи взагалі можливо ставити питання таким чином? Вказується, що біографічний метод історико-філософського дослідження уможливлює культурологічне прочитання життєдіяльності філософа в контексті унікальності місця і часу як хронотопу життєвчення. Хронотоп як "часпростір" (М. М. Бахтін) задає у певний період часу згущення його прикмет, у результаті чого у певному місці культурного простору народжується унікальний образ мислителя. Хронотоп задає неповторність філософських запитів мислителя. Розгляд його концепції крізь призму прожитого життя дає можливість зіставляти обґрунтоване і практиковане і за їх збігу вести мову про життєвчення філософа. У першій частині статті розглядаються "часпростори", в яких відбуваються мислителі домодерної культури: Сократ, Плотін, Фома Аквінський і Сігер Брабантський.

Ключові слова: життєвчення, хронотоп, духовні вправи, філософ, Сократ, Плотін, Фома Аквінський, Сігер Брабантський.

Постановка проблеми. Г. Арендт у промові на честь присвоєння їй премії Зоннінга за внесок в європейську культуру (1975) [5] оприлюднила свої міркування щодо місії фрілософа в сучасному світі. Вона зауважила, що традиційний для фрілософра споглядальний спосіб життя (vita contemplativa) у XX ст. поступається місцем активній включеності у громадське життя в модусі vita activa. Вся ії̈ мислиннєва діяльність концентрувалася на суспільно-політичному житті Заходу, вона осмислювала резонансні політичні події і надавала свої тексти не лише спеціально підготовленій аудиторії, але і широкій освіченій публіці переконливо і нетривіально. Пережите, відчуте і продумане знайшло відбиток у всіх їі текстах, а сформульовані на основі цього ціннісні регулятиви визначили форму і зміст її публічних дій.

Цей конкретний приклад осягнення фрілософом своєї місії дає привід замислитися над питанням призначення фрілософра у світі. Така, на перший погляд, суто фрілософська проблематика може бути розглянута в культурологічному ключі: який вплив на особу, яка мислить, мають час і місце її життя і чи взагалі можливо ставити питання таким чином?

Аналіз досліджень і публікацій. Почнемо з останнього питання, воно носить радше методологічний характер. В історико-фрілософрських дослідженнях наявні дві взаємовиключні точки зору на особистісний фрактор в історико-філософському пізнанні. Одна з них у сучасній англомовній літературі називається компартменталізмом (з англ. compartment - розділення на відсіки, дроблення) i полягає в утвердженні фрілософії як стрункої концептуальної системи, "чистої філософііі", заняття, що "має свій цілком самобутній та раз і назавжди встановлений предмет, свої самодостатні методи, свій фріксований дисциплінарний та інституційний статус" [17, с. 3]. Відповідно, "життя фрілософа абсолютно нічого не дає для розуміння його вчення, отже, їх потрібно розглядати окремо" [15, с. 3].

За іншою точкою зору, у життєдіяльності мислителя убачається ключ до розуміння його фрілософііі. Духовне життя фрілософра, ангажованість певними проблемами зумовлюють його мислення, визначають розгортання теоретичних пошуків. В історико-фрілософрських дослідженнях така індивідуально орієнтована тенденція отримала назву "біографрічний поворот" [16, с. 23]. Саме ця, друга точка зору уможливлює культурологічне прочитання життєдіяльності фрілософра в контексті унікальності часу і місця.
Чому людина відчуває потребу у мисленні, у філософському розмислі? Г. Арендт у вже згадуваній промові зазначала, що потреба у філософії виникає тоді, коли "питання, що стосується головних умов людського життя, яке саме по собі, по суті, таке ж старе, як людський рід, набуває надзвичайної гостроти" [5, с. 40]. Історичні обставини, злами особистої долі, визначені ними, зумовлюють специфріку мислення, постановку фрілософських питань. Арендт підкреслювала, що фрілософські питання ставляться наодинці: "3 часів Платона мислення визначається як беззвучний діалог із самим собою; тільки так я можу скласти собі компанію і бути нею задоволений. Філософія - це одиночна справа" [5, с. 40].

До цієї думки, незалежно від Арендт, прийшов їі молодший сучасник М. Мамардашвілі, міркуючи про буття людини в культурі. Питання про людину в культурі $\epsilon$ питанням про реальні духовні запити. "Відповідь на нього не може бути остаточною, завершеною хоча б тому, що ми самі собі його адресуємо" [14, с. 148]. У статті "Думка в культурі" у світлі розглядуваної проблематики важливо заффіксувати два моменти. По-перше, наявність майже тотожної арендтівській позиції щодо фрілософування як діалогу з самим собою. По-друге, очевидним $є$ вихід так заданої проблематики на розмисли про духовні витоки, про європейську культуру взагалі. "Я хочу сказати, що якщо ми його (це питання - М.Р.) адресуємо, то, значить, питаємо себе про свої витоки, тобто шукаємо возз'єднання 3 нашою духовною батьківщиною, а саме з... європейською культурою" [14, с. 148]. (Слід зазначити, що у тексті Мамардашвілі вказано "з християнською європейською культурою". Очевидно, у цьому формулюванні відбилося повсякчасне звернення інтелектуалів пізньорадянського часу до цінностей християнства як невід'ємної складової європейської культури, що заперечувалося радянською ідеологією протягом тривалого часу. Але оскільки у даній статті означення "християнський" потребуватиме додаткових пояснень і зайве ускладнить текст, то його наразі опущено). Таким чином філософ проводить думку про історичну зумовленість мислення, особистісний вимір філософуванння, про його конкретизацію у просторі і часі західної культури.

Тут варто пригадати категорію хронотопа, запропоновану М. М. Бахтіним для дослідження структури художнього твору. "Хронотоп - часпростір, сутнісний взаємозв'язок часових і просторових відносин, художньо осмислених в літературі" [6, с. 341]. Бахтін зазна- 